\title{
Alternative for the Use of Sewage Sludge in Romania
}

\begin{abstract}
LARISA PURDEA, CARMEN OTILIA RUSANESCU*, MARINA CRISTINELA TUCUREANU*
Politehnica University of Bucharest, Faculty of Biotechnical Systems Engineering, 313 Splaiul Independentei, 060042, Bucharest, Romania

In Romania, formore than $50 \%$ of the amount of sewage sludge, the life cycle ends with the most unfavorable stage of the waste management hierarchy or storage. This study indicates the feasibility of using sewage sludge as an alternative fuel in clinker rotary kilns by presenting theoretical information and personal research data.
\end{abstract}

Keywords: sewage sludge, disposal, cement industry, emissions, heavy metals

Macro and micro levels tend to optimize and streamline all processes with minimal impact on the environment [5, $18,20,22,24,29-37]$. An ambitious package of measures was adopted by the European Commission on 2 December of 2015 regarding the circular economy. These measures consist of a European Union plan, which aims to establish principles for the entire life cycle of a product: from conception, material acquisition, production, consumption to waste management and the secondary raw material market. Thus, sustainable development will get a real outlook.

The sewage treatment process generates as an undesirable byproduct sludge, called sewage sludge, which requires special management both from the point of view of environmental protection and from an economic point of view. According to the Decision 856 / 16.08 .2002 on waste management records and for the approval of the list of wastes, including hazardous waste, this secondary product is classified as waste category 19 - waste from waste treatment facilities, from wastewater treatment plants waste water and water treatmentfor industrial water supply. The European Commission has proposed to reduce waste by 2050 by $50 \%$, including sludge from sewage treatment [12].

Conventional sludge disposal methods, such as storage in specially designated areas for waste disposal, disposal in seas or rivers, and land application, are under pressure and protest from people involved in this area, from NGOs and also from environmental authorities. On the other hand, the rise in fuel prices, the rapid reduction of non-renewable resources due to increased demand, population awareness and climate change problems are of interest in lengthening the life cycle of products, rethinking how to deal with waste, implicitly considering waste as a valuable resource $[4,13]$. According to these facts, the sewage sludge can present several forms of recovery. Incineration is considered an efficient way of removing sludge due to its potential for electricity generation. But this process results in another waste - ashes. The feasibility of using ash from incineration of sewage sludge as a substitute for cement and / or sand in cement-based building materials is another encouraging aspect of incineration [14], but this additionally involves major costs and very advanced management [15].

Both theory and practice demonstrate that sludge is typically treated prior to disposal to reduce water content, fermentation tendency and pathogens by using treatment processes such as thickening, dehydration, stabilization, disinfection and drying thermal $[10,16,17]$. This indicates the possibility of using other sewage sludge without the need for further treatment [27]. The following section presents the study of the use of secondary by products from the cement industry as an alternative fuel [26].

\section{Experimental part}

Materials and methods

According to studies conducted for the European Union on sludge, it can be said that for $15 \mathrm{EU}$ countries, the final disposal of the sludge, respectively its reuse in agriculture and composting, is $53 \%$ of the produced quantity, and for incineration $20 \%$ of the produced quantity. As for the $13 \mathrm{EU}$ Member States that joined after 2003, they have remained the classic way of removing sludge by storing [11]. Due to the obligations laid down in Directives 91/271 / EC and DE (86/278/EC), which highlight the regulation of the correct use of sludge, the most widely used waste recovery method in all $28 \mathrm{EU}$ countries is use as a fertilizer for soil in agriculture, and incineration is practiced for final disposal [21].

It can be seen that almost $50 \%$ of sewage sludge get on the landfill, which means a lost for Romanian economy and a threat for the environment. To analyze the components of the sewage sludge, the XRD method was

\begin{tabular}{|l|l|l|l|l|l|l|}
\hline Time & $\begin{array}{l}\text { Sewage sludge } \\
\text { production }\end{array}$ & $\begin{array}{l}\text { Disposal } \\
\text { landfill }\end{array}$ & Agriculture use & $\begin{array}{l}\text { Compost } \\
\text { and other }\end{array}$ & Incineration & $\begin{array}{l}\text { Disposal } \\
\text { other }\end{array}$ \\
\hline 2000 & 0 & 0 & 0 & 0 & 0 & 0 \\
\hline 2005 & 67.8 & 55.9 & 0.7 & 4.7 & 0 & 6.6 \\
\hline 2006 & 225.6 & 145.4 & 0.4 & 3.9 & 0 & 6.7 \\
\hline 2007 & 99.6 & 44.4 & 0.7 & 2.7 & 0 & 7.7 \\
\hline 2011 & 114.1 & 53.9 & 1.8 & 0.2 & 0 & 1.5 \\
\hline 2015 & 210.45 & 104.23 & 10.64 & 0 & 0.5 & 40.91 \\
\hline
\end{tabular}

Table 1

SEWAGE SLUDGE PRODUCTION AND DISPOSAL IN ROMANIA [DATA IN THOUSAND TONS] [10]

\footnotetext{
* email: rusanescuotilia@gmail.com; tmc.marina@yahoo.com
} 
applied, thus observing the large amounts of ash sludge ash remaining from inorganic incineration $[4,6,7,9,12$, $14,16]$. The general characteristics of the ashes have also been reported in the literature [14] and show that the major elements in the ash are Si, Al, Ca, Fe and P. Crystalline forms of these elements are invariably quartz $\left(\mathrm{SiO}_{2}\right)$, whitlockite $\left(\mathrm{Ca}_{3}\left(\mathrm{PO}_{4}\right)_{2}\right)$ and hematite $\left(\mathrm{Fe}_{2} \mathrm{O}_{3}\right)$. The amorphous glass phase content may vary considerably between the ash samples. This is an important feature when it is considered that ash is a potential pozzolanic additive in mixed cements. Ash produced by thermal treatments of sewage sludge have common cement properties. For example, the major elements present in the sewage sludge ash are the same as main cement elements, the hydraulic properties of ash being the same as those of cement tones [25].

The sludge may undergo one or more treatments that result in a solid alternative fuel with a low to medium energy content that can be used in the cement industry. The use of sew age sludge in the cement industry may be of global interest due to the increase in sludge production and the limitation of land availability when used as a soil conditioning agent. Some of the advantages of this method are: reducing waste disposal costs, ensuring excellent sustainable practices, preserving the environment, partially solving the problem of limiting land for landfills. Traditional fuels used in the cement manufacturing process are gas, oil or coal, while alternatives may be materials such as used oils, plastics, car residues, used tires $[9,20,36]$ and sewage sludge.

The use of this type of sludge as an alternative fuel in clinker furnaces also solves the problem of ash resulting in incineration. The resulting ash is incorporated into the cement matrix, and the minerals will be incorporated into the clinker during the combustion process [7]. Different types of waste can replace primary raw materials and / or fossil fuels from cement production and thus contribute to saving natural resources. The essential characteristics of the process of using sewage sludge as an alternative fuel are the high particle-retaining capacity of heavy metals and the chemical-mineralogical incorporation of nonvolatile heavy metals into the clinker matrix. Of course, there are certain physico-chemical characteristics imposed by the cement industry for alternative fuels, and the most important from the point of view of technical feasibility are: the lower calorific value, which must be at least 8.5 $\mathrm{G} / \mathrm{t}$, respectively the humidity that must not exceed $15 \%$.

The calorific value of the sludge depends on the organic content and moisture content of the sludge. Dry sludge of waste water with high organic content has a high calorific value. Waste from sewage sludge treatment processes play a minor role as a substitute for raw materials due to their chemical composition [10]. Due to the high temperature in the furnace (min 1450 degrees Celsius in the material), the organic content of the sludge will be completely destroyed. Therefore, the use of waste containing volatile metals (mercury, cadmium, thallium) or volatile organic compounds can lead to an increase in emissions of mercury, cadmium, thallium or organic emissions (eg organic chemicals) when used improperly. Greater attention should be paid to waste containing components that can volatilize at lower temperatures before the calcination zone. They must be introduced into the high temperature zones of the furnace system [8]. Dust slurries have a content of organic substances (about 40$45 \%$ by weight), therefore using this alternative fuel in clinker production will save $\mathrm{CO}_{2}$ emissions. According to the preset IPCC value of biomass-based solid fuel, the $\mathrm{CO}_{2}$ emission factor of the dry scrub is $110 \mathrm{~kg} \mathrm{CO} / \mathrm{G}$ without considering the biogenic content [3]. Sewage sludge from a wastewater treatment plant in Romania has the characteristics that can be obtained on a cement plant. Fuel could be used along with traditional fuels. The important restriction of the sludge and coal ratio is the emission of heavy metals and dust.

\section{Results and discussions}

Often, in the use of cement kiln waste, total organic carbon and mercury emissions, especially when using sewage sludge, are monitored in clinker furnace gas (in some cases continuously) in addition to regular continuous measurements of dust, $\mathrm{NO}_{x^{\prime}} \mathrm{SO}_{2}$ and $\mathrm{CO}$ [14].

The analysis report of a sample of sewage sludge showed that this waste, or better known as product, also contains about $8 \%$ of oil products (table 2 ).

Table 2

ANALYSES REPORT FOR A ROMANIAN SEWAGE SLUDGE SAMPLE

\begin{tabular}{|l|l|l|}
\hline \multicolumn{1}{|c|}{ Parameter } & \multicolumn{1}{c|}{ Unit } & \multicolumn{1}{c|}{$\begin{array}{c}\text { Average (or } \\
\text { single value) }\end{array}$} \\
\hline Calorific Value & $\mathrm{GJ} / \mathrm{t}$ & 8.92 \\
\hline Moisture & $\%$ & 12.2 \\
\hline Mercury & $\mathrm{mg} / \mathrm{kg}$ & 0.809 \\
\hline Cadmium & $\mathrm{mg} / \mathrm{kg}$ & 2.17 \\
\hline Plumb & $\mathrm{mg} / \mathrm{kg}$ & 42.5 \\
\hline Chromium & $\mathrm{mg} / \mathrm{kg}$ & 73 \\
\hline Copper & $\mathrm{mg} / \mathrm{kg}$ & 370 \\
\hline Manganese & $\mathrm{mg} / \mathrm{kg}$ & 460 \\
\hline Arsenic & $\mathrm{mg} / \mathrm{kg}$ & 6.14 \\
\hline Zinc & $\mathrm{mg} / \mathrm{kg}$ & 985 \\
\hline Petroleum products & $\mathrm{mg} / \mathrm{kg}$ & 7780 \\
\hline
\end{tabular}

In the initial form, the sewage sludge had $31.9 \%$ humidity, with $7.33 \mathrm{G} / \mathrm{t}$, but after thermal treatment, the humidity decreased with $62 \%$ and the calorific value increased with almost $22 \%$.

In this case, taking into account the results of the analyzes and the benefits of using sewage sludge as an alternative fuel, the next steps are the study of the environmental impact of the emissions resulting from the co-incineration process. The theory states that metals that are or have refractory or non-volatile compounds such as $\mathrm{Ba}, \mathrm{Be}, \mathrm{Cr}, \mathrm{As}, \mathrm{Ni}, \mathrm{V}, \mathrm{Al}, \mathrm{Ti}, \mathrm{Ca}, \mathrm{Fe}, \mathrm{Mn}, \mathrm{Cu}$ and Ag do not form a cycle in the clinker furnace, such as chlorine or sulphates, but are abstracted from the mineralogical structure of the clinker. In this case, in waste gases, the only emissions are dust-related, depending only on the entry and efficiency of dust segregation. Consequently, emissions are generally very low [23].

Metals that are or have semi-volatile compounds, such as $\mathrm{Sb}, \mathrm{Cd}, \mathrm{Pb}, \mathrm{Se}, \mathrm{Zn}, \mathrm{K}$ and $\mathrm{Na}$, condense as sulphates or chlorides at temperatures between 700 and $900^{\circ} \mathrm{C}$ and produce inner cycles. Thus, the semi-volatile elements that accumulate in the furnace preheating system are precipitated again in cyclones, but almost completely reach the clinker [23]. Particular attention should be paid to mercury, which is volatile, meaning that mercury compounds mostly pass through the furnace and preheater, depending on the temperature of the residual gas only partially adsorbed by the raw gas dust [1,2]. 
In the BestAvailable Techniques documentation, which was based on studies of about 200 clinker furnaces, it is specified that volatile organic compounds (VOC) emissions may occur in the primary stages of the process (preheater) when the organic matter that is present in the bulk is volatilized, as alternative fuels are heated. The organic substance is released between 400 and $600{ }^{\circ} \mathrm{C}$. VOC content of clinker kiln emissions is typically between 1 and $80 \mathrm{mg} / \mathrm{Nm}^{3}$, measured as COT. However, in rare cases, emissions may reach $120 \mathrm{mg} / \mathrm{Nm}^{3}$ due to the characteristics of the raw materials [14].

In 2005, the data showed that the cement industry accounts for nearly $5 \%$ of global anthropogenic $\mathrm{CO}$ emissions [20], but a recent study shows that global cement production has increased in recent years, putting the sector in third place - the largest source of anthropogenic carbon dioxide emissions [28]. Knowing that sewage sludge has a relatively high net calorific value of $8.92 \mathrm{GJ} / \mathrm{t}$ and a carbon dioxide emission factor much lower than that of coal when treated in a cement kiln, I still present a comparison of this perspective.

Table 3

COAL CHARACTERISTICS [19]

\begin{tabular}{|c|c|c|}
\hline Parameter & Unit & Value \\
\hline Net Power Heat & $\mathrm{GJ} / \mathrm{t}$ & 25.80 \\
\hline Emission Factor & $\mathrm{kg} \mathrm{CO} / \mathrm{GJ}$ & 94.60 \\
\hline Biomass & $\%$ & 0.00 \\
\hline & & \\
\hline
\end{tabular}

In Romania are 7 cement plants and if every Romanian cement plant would use 10,000 t of dried sewage sludge, would be replaced approximate $25,000 \mathrm{t}$ of coal, respectively would be saved almost $60,000 \mathrm{t}$ of $\mathrm{CO}_{2}$ emissions.

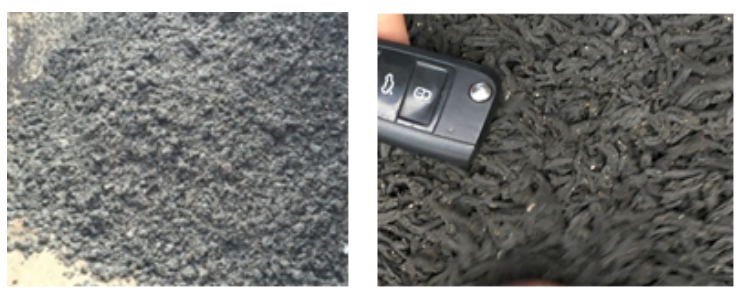

Fig. 1 Dried sewage sludge

Low volatility compositions in sewage sludge, such as $\mathrm{Cd}$ and $\mathrm{Pb}$, can make a much greater contribution to increased emissions of heavy metals because they easily evaporate and enter the combustion gases during decomposition and heat calcination, while non-volatile metals remain mainly in the cement clinker [7].

At a cement plant where the thermoenergetic ratio of the alternative fuels used was about $20 \%$, the values of the heavy metal concentrations were as shown in the following table.

Heavy metals and mercury emissions measured at the evacuation route of the clinker plant had low values with a fossil fuel replacement rate of $20 \%$. Approximately $70 \%$ of the alternative fuels used were used tires, which, according to a 2006 study [26], have a content of approximately 27 $[\mu \mathrm{g} / \mathrm{g}] \mathrm{Cd}$ and $458[\mu \mathrm{g} / \mathrm{g}] \mathrm{Pb}$.

Turning our attention to the information presented in Table 4, it is very probable that COT emissions will not increase when sewage sludge is used as alternate fuel in clinker rotary kilns. According to this information, it is probably that the emissions of Toc will notincrease in case of the use of sewage sludge as an alternative fuel in cement industry.
Table 4

HEAVY METAL EMISSIONS WITH 20\% FOSSIL FUEL SUBSTITUTION RATE

\begin{tabular}{|l|c|c|}
\hline \multirow{2}{*}{ Toxicity category } & Value & $\begin{array}{c}\text { Legal limit } \\
\text { (Law 278/2013) }\end{array}$ \\
\cline { 2 - 3 } & $\begin{array}{r}|c| \\
{\left[\mathrm{mg} / \mathrm{Nm}^{3}, 10 \% \mathrm{O}_{2,273 \mathrm{~K}, \text { pressure: }}\right.}\end{array}$ \\
\hline $\mathrm{Hg}$ & 0.0280 & 0.05 \\
\hline $\mathrm{Cd}+\mathrm{TI}$ & $\leq 0.0017$ & 0.05 \\
\hline $\begin{array}{l}\mathrm{Sb}+\mathrm{As}+\mathrm{Pb}+\mathrm{Cr}+\mathrm{Co}+ \\
\mathrm{Cu}+\mathrm{Mn}+\mathrm{Ni}+\mathrm{V}\end{array}$ & $\leq 0.0715$ & 0.5 \\
\hline
\end{tabular}

\section{Conclusions}

The use of sewage sludge as an alternative fuel in clinker production can become one of the most sustainable options for sludge management as it would reduce waste disposal costs, ensure excellent durable practices, reduce consumption non-renewable resources and environmental impact would solve the problem of land restraint for landfills.

According to the information in this study, the emissions resulting from the use of sewage sludge in clinker rotary kilns will not increase significantly. However, during the mud co-incineration process, much attention should be paid to aromatic polycyclic hydrocarbons, volatile heavy metals, total organic carbon emissions.

Romania needs a well-defined strategy for sewage sludge management in order to maximize the value of this resource with the aim of continuously supporting the concept of sustainable development.

\section{References}

1. ACHTERNBOSCH, M., BRAUTIGAM, K.-R., HARTLIEB, N., KUPSCH, C., RICHERS, U., STEMMERMANN, P., Heavy Metals in Cement and Concrete Resulting from the Co-incineration of Wastes in Cement Kilns with Regard to the Legitimacy of Waste Utilisation, 2003.

2. CHATZIARAS, N., THEMELIS, N. J., PSOMOPOULOS, C. S., $12^{\text {th }}$ International Conference on Protection and Restoration of the Environment, 2014, 1521-529.

3.*** Cement Sustainability Initiative, The Cement $\mathrm{CO}_{2}$ and Energy Protocol, World Business Council for Sustainable Development, Version 3, 2014.

4. POPESCU, I., FRONTASYEVA, M., STIHI, C., CIMPOCA, Ghe., RADULESCU, C., GHEBOIANU, A., OROS, C., VLAICU, Ghe., PETRE, C., BANCUTA, I., DULAMA, I., Romanian Journal of Physics, 55, 7-8, 2010, pp. 821-829.

5. RUSANESCU, C.O., JINESCU, C., RUSANESCU, M., ENESCU, M. C., ANGHELINA, F. V. STOIAN, E.V., DESPA, V., Mat. Plast., 54, no. 3, 2017, p.409-413.

6.MURARESCU, O., PEHOIU, G., RADULESCU, C., DULAMA, I.D., TEODORESCU, S., STIRBESCU, R. M., MURATOREANU, G., Rev. Chim.(Bucharest), 69, no. 5, 2018, p.1037-1040.

7. DESPA, V., ANGHELINA, F. V., IANCU, D., RUSANESCU, C. 0., J OURNAL OF SCIENCE AND ARTS, YEAR 17, 4, 41, 2017, p. 839-852.

8. BRIVIO, E., Grouth Internal Market, Industry, Entrepreneurship and SMEs, European Commission, Bruxelles, 2017.

9. RUSANESCU, M., RUSANESCU, C. 0., VOICU, GHE, BEGEA, M., Rev. Chim.(Bucharest), 69, no. 7, 2018, p. 1695-1698.

10. SCHORCHT, F., KOURTI, I., SCALET, B. M., ROUDIER, S., SANCHO, L. D., Best Available Techniques (BAT) Reference Document for the Production of Cement, Lime and Magnesium Oxide, Luxembourg Publications Office of the European Union, ISSN 1831-9424, 2013, p 9597, 75-78, 70-72. 
11. *** Official Journal of the European Union, 181, Commission Regulation (EU) No 601/2012, Annex VI - Reference Values for Calculation Factors, (NCV), 12.07.2012.

12. DUNEA, D., IORDACHE, S., RADULESCU, C., POHOATA, A., DULAMA, I. D., Romanian J ournal of Physics, 61, 7-8, 2016, p. 1354-1368.

13. RUSANESCU C.O., POPESCU I. N., DAVID L., $3^{\text {rd }}$ International Conference on Environmental and geological science and Engineering (EG' 10), 2010, p. 175-180.

14. KAPPEL, W., JIPA, S., ZAHARESCU, T., SETNESCU, R., OROS, C., Rev. Chim. (Bucharest), 57, no. 3, 2006, p. 290-292.

15. RUSANESCU, M., PURCAREA, A. A., RUSANESCU, C.O., Conference: $6^{\text {th }}$ International Conference on Management and Industrial Engineering - ICMIE, 2013, p. 395-400.

16. JIPA, S., ZAHARESCU, T., SETNESCU, R., KAPPEL, W., OROS, C., GORGHIU, L. M., Nuclear Instrumentations and Methods in Physics Research, Section B: Beam Interactions with Materials and Atoms, 265, 2007, p. 305-308.

17. JINESCU, C., Mat. Plast. 51, no. 3, 2014, p. 235-240.

18. RUSANESCU, C. O., JINESCU, C., RUSANESCU, M., BEGEA, M., GHERMEC, 0., Rev. Chim. (Bucharest), 69, no. 1, 2018, p. 105-111.

19. *** WBCSD Cement Sustainability Initiative - Cement $\mathrm{CO}_{2}$ and Energy Protocol, Version 3.02, $\mathrm{CO}_{2}$ Emissions and Energy Inventory, Default $\mathrm{CO}_{2}$ Emission Factors for Fuels, 132011.

20. RUSANESCU, C. O., RUSANESCU, M., ANGHELINA, F. V., J ournal of optoelectronics and advanced materials, 15, 7-8, 2013, p. 724 - 729. 21. World Business Council for Sustainable Development, The Cement Sustainability Initiative Progress Report, 2005.

22. RUSANESCU, C. O., RUSÃNESCU, M., ANGHELINA, FL. V., BRATU V., Romanian Reports in Physics, 68, No. 1, 2016, p. 278-293.

23. DOGARU, D., JINESCU, C., DOGARU, GHE., Rev. Chim. (Bucharest), 60, no. 8, 2009, p.826-829
24. GHERMEC, O., GHERMEC, C., DUBOVAN, S., RUSANESCU, C. O., Environmental Engineering and Management J ournal, 12, 10, 2013, p. 2019-2023.

25. CRIVINEANU, M. F., DUMITREL, G. A., PERJU, D. S., JINESCU, C., NEGREA, A., Rev. Chim.(Bucharest), 63, no. 10, 2012, p. 1051-1055.

26. PATROESCU, V., J INESCU, C., COSMA, C., CRISTEA, I., BADESCU, V., STEFAN, C. S. Rev. Chim. (Bucharest), 66, 4, 2015, p. 537-541.

27. MUNTIANU, G., URSU, A. V., JINESCU, C., DJ ELVEH, G., NISTOR, I. D., JINESCU, G. Rev. Chim.(Bucharest), 66, no. 3, 2015, p. 295-298.

28. JINESCU, V., PETRESCU, S., JINESCU, C., Rev. Chim. (Bucharest), 64, no. 6, 2013, p. 630-638.

29. RUSANESCU, M., RUSANESCU, C. O., VOICU, G., BEGEA, M., Rev. Chim. (Bucharest), 69, no. 7, 2018, p. 1695-1698.

30. CORABIERU, A., VELICU, S., CORABIERU, P., SOHACIU, M., Rev. Chim. (Bucharest), 70, no. 2, 2019, p. 470-474.

31. DURBACA, I., Mat. Plast., 52, no. 1, 2015, p. 43

32. ANDREI, V.A, MALINOVSCHI, V., RADULESCU, C., IONITA, I., TOROK, G., COACA, E., MARIN, A. H., JOURNAL OF SCIENCE AND ARTS, 1, 2019, p. 185-194.

33. RODICA, L. , DULAMA, I. D., RADULESCU, C., BUCURICA, I. A., STIRBESCU, R. M., TEODORESCU, S., Journal of Science and Arts , Year 18, No. 4, 45, 2018, p. 1033-1044.

34. SOHACIU, M., NICOLAE, A., PREDESCU, CR., VELICU, S., CALEA, $\mathrm{GH}$., Environmental Engineering and Management J ournal, 8, 4, 2009, p. 997-1001.

35. DURBACA, I., IATAN, R., DURBACA, A.C., SACUIU, V., CORLECIUC, M. M., RUSÃNESCU, C.O., Mat. Plast., 56, no. 1, 2019, p.156-162.

36. RUSANESCU, C. O., RUSANESCU, M., JOURNAL OF MINING AND METALLURGY SECTION B-METALLURGY, 49, 3, 2013, p. 353-356.

37. RADULESCU, C., IORDACHE, S., DUNEA, D., STIHI, C., DULAMA, I.D., Romanian J ournal of Physics, 60, 7-8, 2015, p.1171-1182.

Manuscript received: 14.12 .2018 